\title{
REQUALIFICAÇÃO DO EDIFÍCIO RIACHUELO NO CENTRO HISTÓRICO DE SÃO PAULO
}

PAULO JULIO VALENTINO BRUNA PAULO BRUNA ARQUiTETOS ASSOCIADOS, SÃo PAULO, SÃO PAULO, BRASIL

Arquiteto e professor da Faculdade de Arquitetura e Urbanismo da Universidade de São Paulo.

E-mail: pb@paulobruna.com.br

SONIA MARIA MILANI GOUVEIA

Arquiteta e mestre pela Faculdade de Arquitetura e Urbanismo da Universidade de São Paulo.

DOI

http://dx.doi.org/10.11606/issn.1980-4466.v0iesp22p193-216 


\section{REQUALIFICAÇÃO DO EDIFÍCIO RIACHUELO NO CENTRO HISTÓRICO DE SÃO PAULO \\ PAULO JULIO VALENTINO BRUNA \\ SONIA MARIA MILANI GOUVEIA}

\section{RESUMO}

O Edifício Riachuelo foi projetado e construído entre 1942 e 1945 pelos engenheiros Lindenberg \& Assumpção, com 17 pavimentos. O primeiro proprietário foi a Associação de Empregados do Comércio de São Paulo, que ocupava apenas alguns andares com atividades sociais. Os demais foram vendidos. O espaço ocupado pela Associação, após 1978, foi utilizado por uma escola de contabilidade e, quando esta saiu, o edifício foi ficando pouco a pouco vazio. Em 1994, foi invadido por moradores de rua. A expulsão dos invasores pelos policiais acarretou uma profunda depredação do imóvel, com destruição de portas, janelas, sanitários, elevadores e prumadas de águas pluviais. A Prefeita Marta Suplicy, durante seu governo (2000/2004), iniciou o programa Morar no Centro, que visava a ocupação do centro histórico, não apenas por setores da administração municipal, mas também por moradores em um sistema de "locação social". Em 2004, o escritório Paulo Bruna Arquitetos foi contratado pela Cohab-SP para reabilitar o edifício. A área do terreno é de $516 \mathrm{~m}^{2}$ e a área total construída é de $7.870,54 \mathrm{~m}^{2}$. A recuperação procurou respeitar a lógica construtiva original. Entre os salões de escritórios havia paredes de alvenarias de tijolos maciços que foram mantidas porque são integradas no contraventamento da estrutura. Assim, basicamente cada escritório transformou-se em um apartamento. Foi possível acomodar 120 unidades, variando de $28 \mathrm{~m}^{2}$ a $48 \mathrm{~m}^{2}$ de área útil. Muitos têm balcões e portas-janelas privativas, que foram mantidos, pois a fachada foi classificada como bem de valor histórico. Os apartamentos acabaram sendo vendidos e os moradores valorizam e conservaram o condomínio de maneira exemplar.

PALAVRAS-CHAVE

Edifícios residenciais. Patrimônio ambiental urbano. Centros históricos. 


\section{REDEVELOPING THE RIACHUELO BUILDING IN SÃO PAULO'S HISTORIC DOWNTOWN \\ PAULO JULIO VALENTINO BRUNA \\ SONIA MARIA MILANI GOUVEIA}

\section{ABSTRACT}

The Riachuelo building with its 17 floors was designed and built between 1942 and 1945 by the engineers Lindenberg \& Assumpção. Its first owner was the São Paulo's Association of Commerce Employees, which occupied only a few floors with social activities. The units in remaining floors were individually sold. The Association left the building in 1978, and the space it occupied was used by an accounting school. When the school left, the building gradually became empty until it was invaded by homeless people in 1994. The expulsion of the invaders by the police led to the deep depredation, including destruction of the property's doors, windows, toilets, elevators and rainwater plumbing. During the administration of Mayor Marta Suplicy (2000/2004), the program Morar no Centro was created aiming to occupy São Paulo's historic downtown, not only with municipal administration offices, but also with residents in a "social lease" system. In 2004, Paulo Bruna Arquitetos was hired by Cohab-SP to rehabilitate the building. The recovery sought to respect the original constructive logic in 5,554 square foot of land area and the 84,717 square foot total constructed area. The solid brick walls that separated the different offices were kept since they are part of the structure's bracing, so basically every office was turned into an apartment, in a total of 120 units, ranging from 301 square foot to 516 square foot of floor space. Many of them include private balconies and balcony doors, and those were kept because the façade has been listed as historical heritage. The apartments were eventually sold and their residents value and maintain the building in an exemplary way.

\section{KEYWORDS}

Residential buildings. Urban environment heritage. Historic downtowns. 


\section{INTRODUÇÃO}

A segunda metade do século XIX representa para São Paulo um período de profundas transformações. Se até 1870 a cidade continuava a ocupar a colina onde havia sido fundado o colégio dos Jesuítas, e a população não passava de 31.000 habitantes, em 1900 a população chegava a 240.000 pessoas.

Nesse período o assim chamado "Triângulo", em cujos vértices estavam a igreja de São Bento, a de São Francisco e a do Rosário, converteu-se em uma área puramente comercial, e durante cinco décadas tornou-se ele o verdadeiro centro da cidade. Nice Lecoq Muller (1958) ao estudar a área central da cidade referiu-se a essa área da seguinte maneira:

Este triângulo formado pelas ruas de São Bento, Direita e Quinze de Novembro, passou a concentrar a maior parte do comercio varejista, das oficinas e 'ateliers', dos escritórios, dos estabelecimentos de crédito e das repartições públicas. Transformou-se no "coração" da Pauliceia e recebeu dos paulistanos a designação de 'cidade' em contraposição aos bairros existentes em sua periferia onde predominavam as habitações.

Se até 1870 a cidade continuava a ser o "burgo de estudantes", cuja vida gravitava em torno da Faculdade de Direito, que funcionava ao lado da igreja e convento de São Francisco, a partir daquela data a capital paulista 
iniciou um crescimento muito rápido e imprevisível ${ }^{1}$. Mudou seu ritmo de vida, passou a conhecer funções novas, modernizou-se e expandiu-se muito além da colina histórica contida pelos rios Tamanduateí e Anhangabaú, em cujo vale ainda havia hortas e plantações de chá.

É possível identificar pelo menos três fatores que explicam o rápido crescimento da cidade na segunda metade do século XIX: a expansão das plantações de café, a multiplicação das estradas de ferro e o súbito aumento da imigração europeia. Pierre Mombeig (1954) ao estudar esse período, usou a expressão "a capital dos fazendeiros", pois foram as novas necessidades provenientes da comercialização do café, novos hábitos e mentalidades desses fazendeiros que alteraram a fisionomia de São Paulo entre 1872 e 1918. Como escreveu Flavio Saes (2004), mais do que simples fazendeiros, cuja riqueza estava fundada na propriedade da terra, eles transformaram-se em empresários urbanos: "são acionistas e dirigentes de estradas de ferro, comerciantes, banqueiros, acionistas e dirigentes de empresas, industriais e frequentemente políticos". Assim, o colapso da bolsa de Nova York em 1929 e por consequência uma profunda crise no comércio de exportações, sobretudo de café, não chegou a afetar a cidade, que ao contrário, transformou-se em uma metrópole industrial. Uma série de fatores conjugou-se para ocasionar o desenvolvimento e o fortalecimento da industrialização em São Paulo: energia elétrica barata e abundante; existência de um mercado consumidor interno, que não mais conseguiu manter seus níveis de importações, afluxo de capitais tanto estrangeiros como nacionais, que não mais encontravam aplicação na expansão das plantações de café; abundante mão de obra operária, que deixou as áreas de cultivo; importante rede de transportes; existência de matérias primas dentro do próprio estado. A migração internacional continuou acelerada, atingindo $7,0 \%$ da população brasileira (HALL, 2004). A população da cidade de São Paulo alcançou a 1 milhão de habitantes em 1930 e já era o maior centro industrial da América do Sul (TASCHNER, 1997). A população do município de São Paulo passou de 3 milhões no ano de seu quarto centenário (em 1954) e chegou ao fim da década (em 1960) com 3,7 milhões.

1. "lnegavelmente, o acontecimento mais importante para a vida da cidade de São Paulo, em toda a primeira metade do século XIX, foi à instalação da sua Academia de Direito, criada pela Lei de 11 de agosto de 1827 e posta a funcionar em março de 1828". MATOS, Odilon Nogueira de. "São Paulo no século XIX", op.cit., v. 2, cap. II, p. 66. 
FIGURA 1

Crescimento populacional de São Paulo. HALL, Michael. "Imigrantes na cidade de São Paulo", cap. 4, in "História da Cidade de São Paulo", vol.

3. Ep citado, pg. 121. MATOS, Odilon Nogueira de, "São

Paulo no século

XIX", cap. 8 do vol.

2. A cidade de São

Paulo, ep. Citado,

Pg. 66. MONBEIG

Pierre, "Aspectos

geográficos do

crescimento de

São Paulo", in O

Estado de S. Paulo

numero especial

de 25 de janeiro

de 1954, transcrito

no Boletim Paulista

de Geografia, $\mathrm{n}^{\circ}$

16 março de 1954

pg. 72.

\section{Growth of the population of São Paulo}

- 1870

- 1900

- 1930

- 1954

- 1960
31.000 inhabitants

240.000 inhabitants

1 million inhabitants

3 million inhabitants

3.7 million inhabitants
FIGURA 2

Vista panorâmica do viaduto do Chá na década de 1920.

TOLEDO, Benedito Lima de, "Prestes Maia e as origens do urbanismo moderno em São Paulo", Empresa das Artes,

Projetos e Edições

Artísticas, S. Paulo, 1996. Fotografia p. 174.

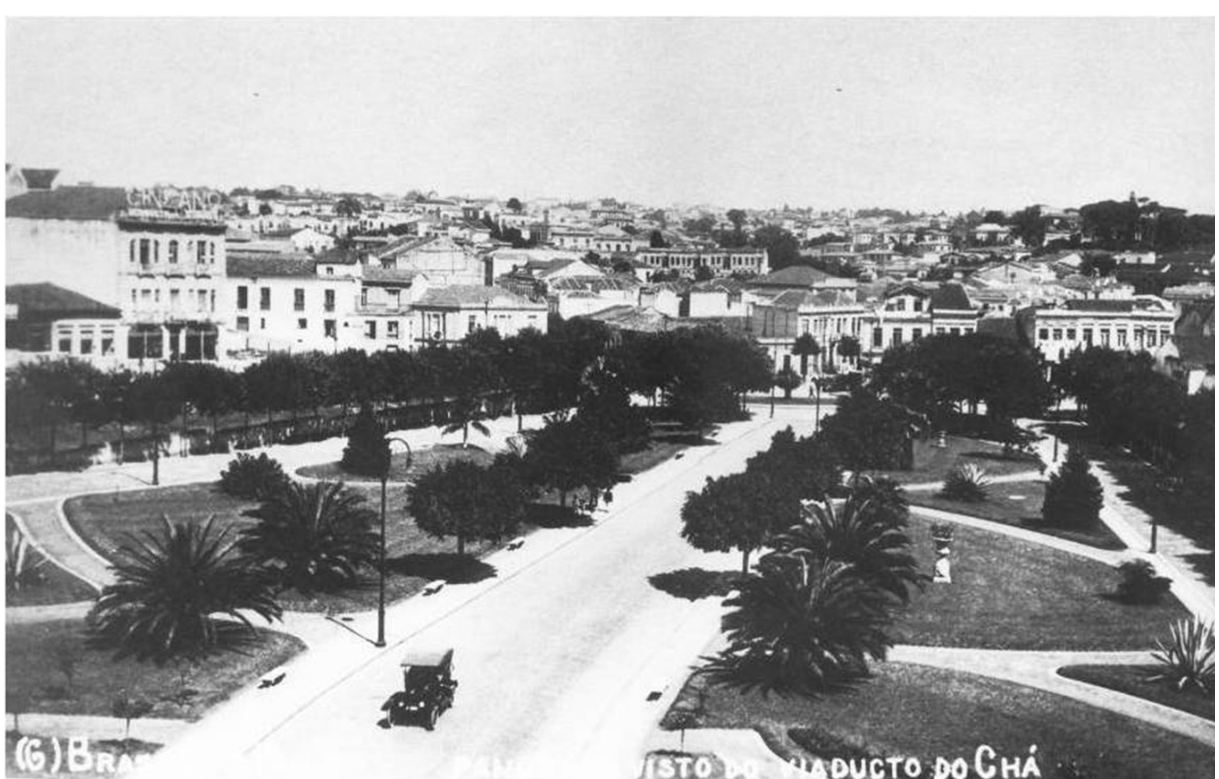

Rev. CPC, São Paulo, n.22 especial, p.193-216, abr. 2017. 
FIGURA 3

Rua Libero Badaró e vale do Anhangabaú na década de 1930.

TOLEDO, Benedito

Lima de, "Prestes

Maia e as origens do urbanismo moderno em São Paulo", Empresa das Artes,

Projetos e Edições Artísticas, S. Paulo

1996. Fotografia p. 174.

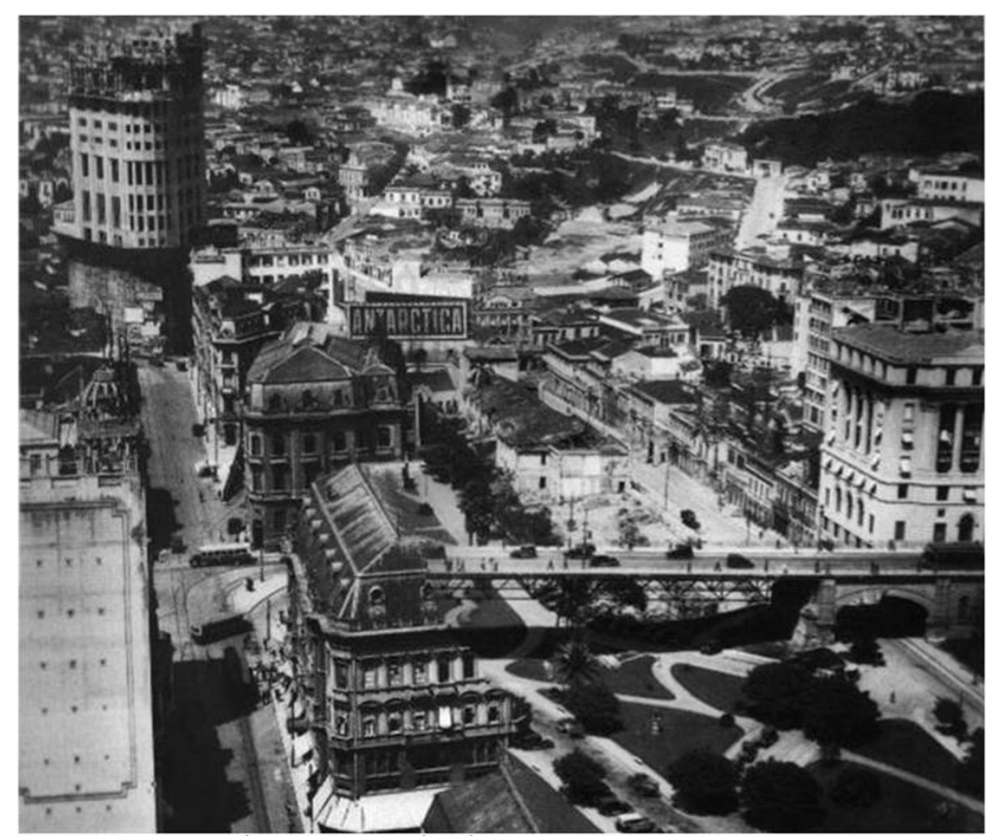

FIGURA 4

Mapa do centro de São Paulo na década de 1930

TOLEDO, Benedito

Lima de, "Prestes

Maia e as origens do

urbanismo moderno

em São Paulo",

Empresa das Artes,

Projetos e Edições

Artísticas, S. Paulo

1996. Fotografia p. 116.

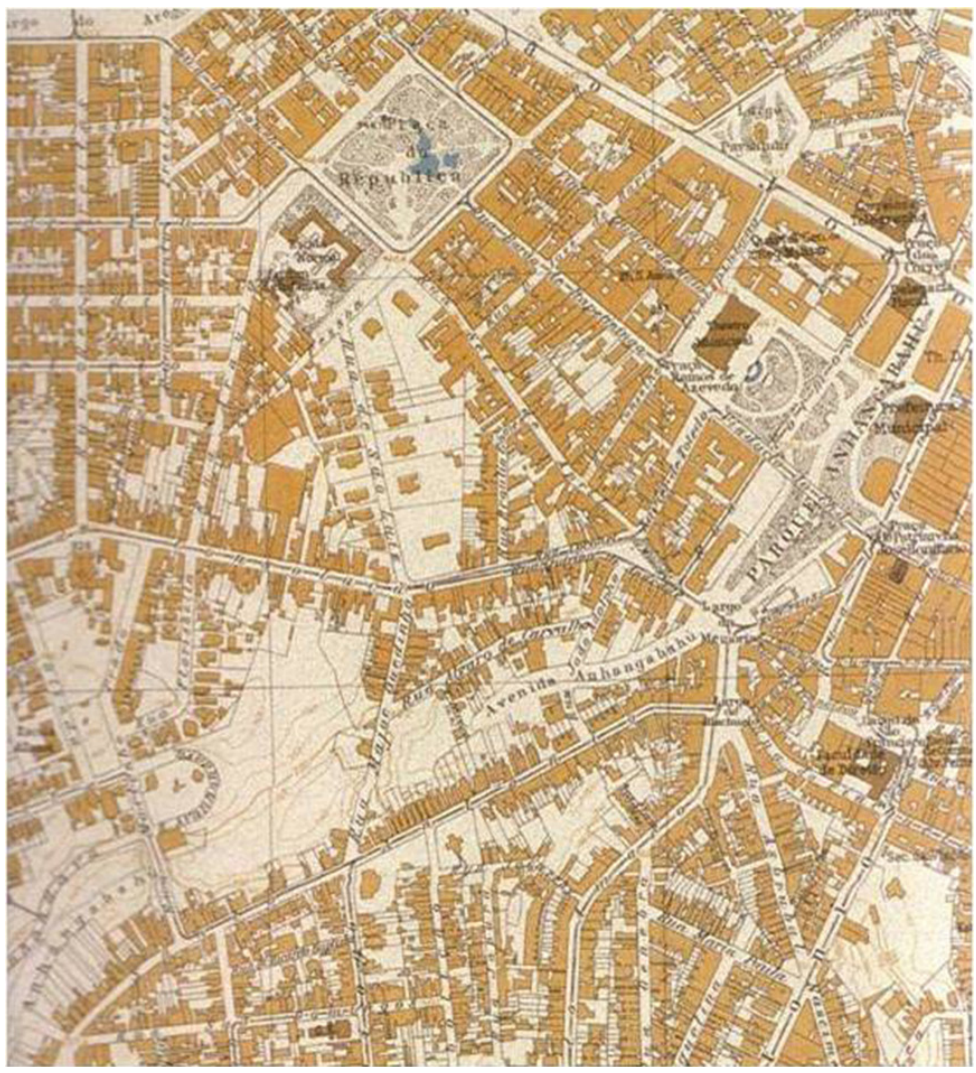


FIGURA 5

Centro da cidade de São Paulo na década de 1940. TOLEDO, Benedito

Lima de, "Prestes Maia e as origens do urbanismo moderno em São Paulo", Empresa das Artes, Projetos e Edições Artísticas, S. Paulo 1996

Fotografia p. 127

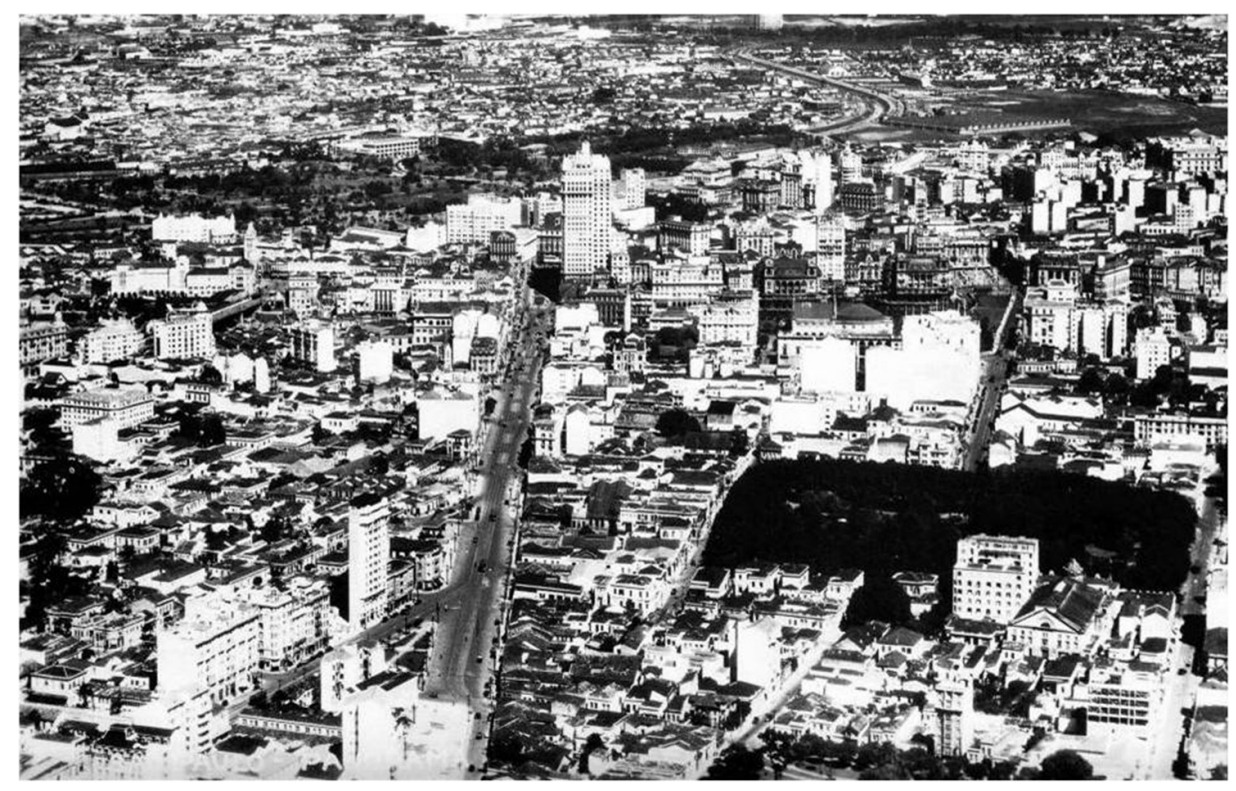

FIGURA 6

Centro da cidade de São Paulo na década de 1950. Fotografia: Peter Scheier

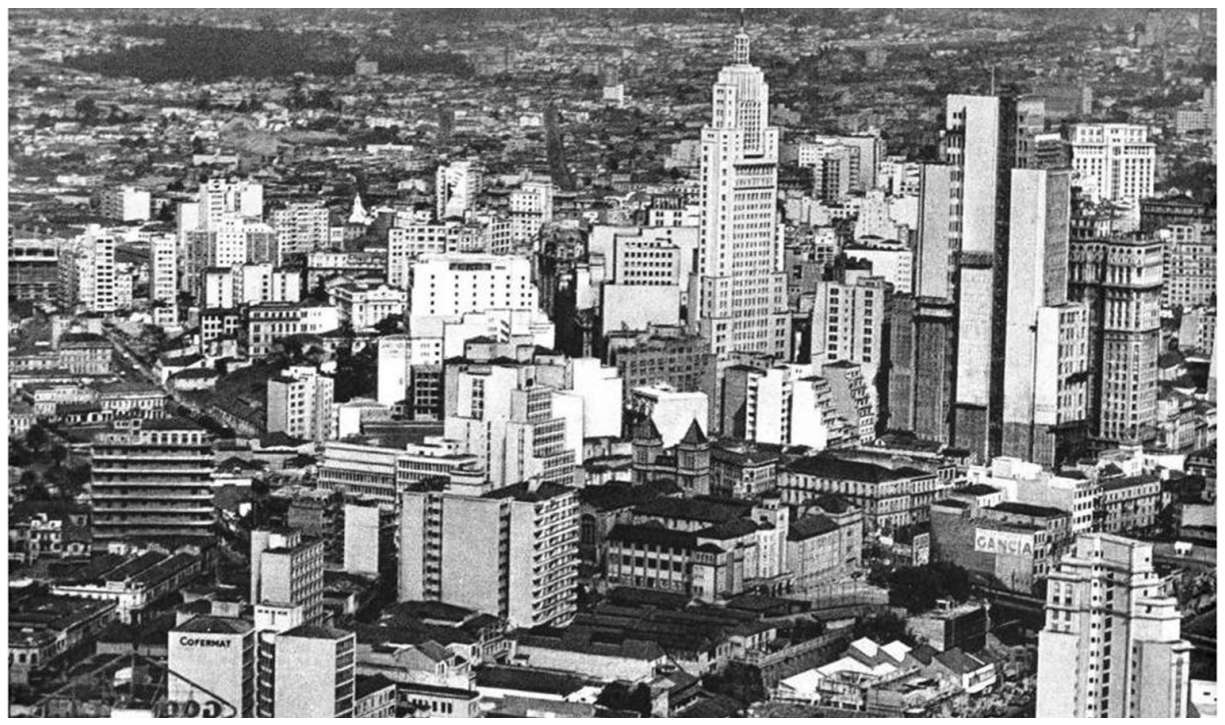

Na década de 1930 o Centro Histórico continuava, porém, a ser o centro de negócios e ruas como XV de Novembro, Boa Vista ou do Ouvidor fervilhavam de pessoas, permitindo a Pierre Denis escrever que no Brasil daquele tempo "São Paulo e o Rio de Janeiro 
FIGURA 7

Vale do Anhangabaú na década de 1950

Fotografia: Peter Scheier.

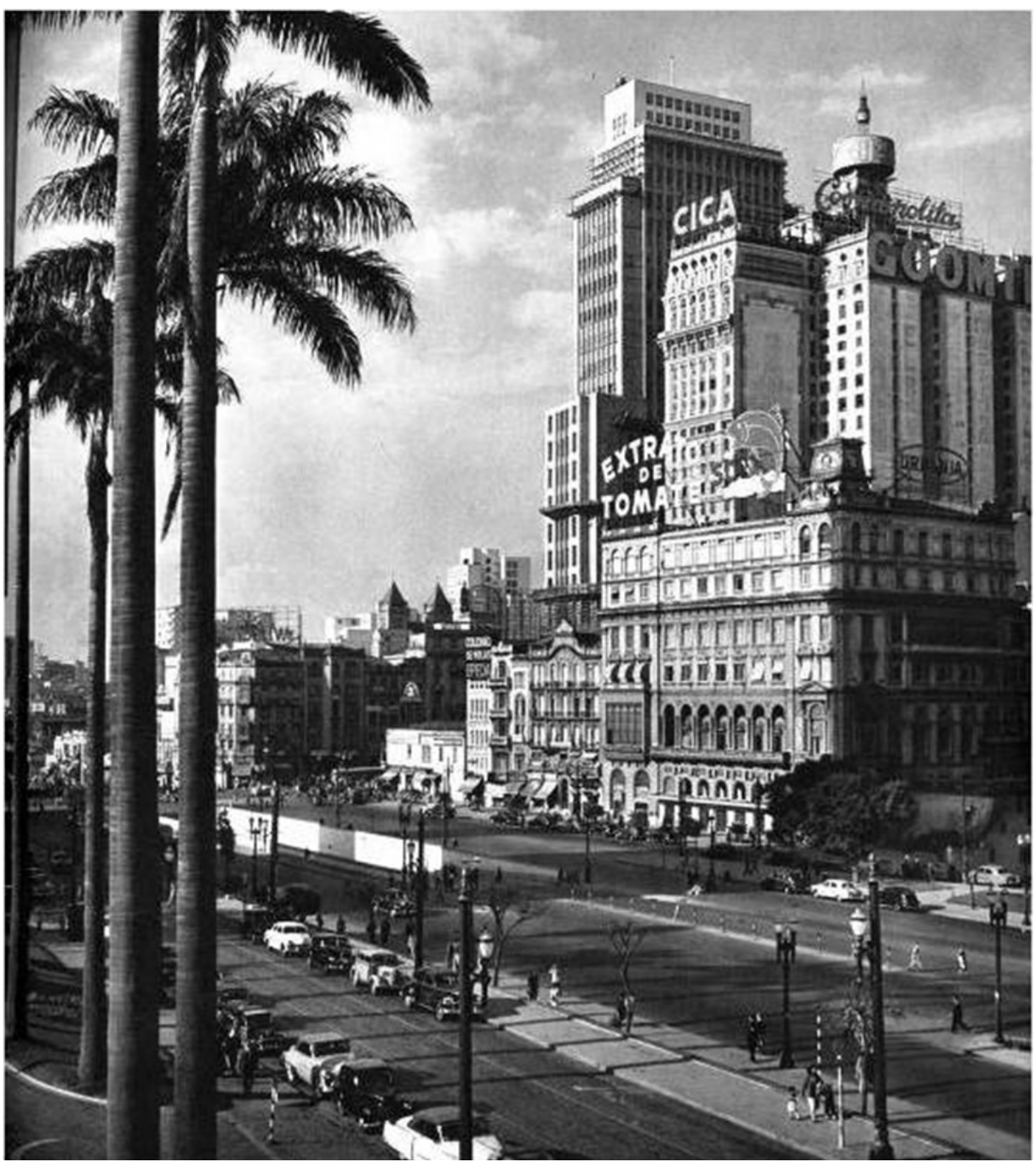

eram as únicas cidades onde se podia encontrar uma multidão"2. Coube aos prefeitos Fabio Prado (1934-38) e Francisco Prestes Maia (1938-45) iniciarem grandes transformações urbanísticas na capital paulista (MEYER, 1991). No Centro Velho abriu-se a Praça do Patriarca (1926) e em 1936 inaugura-se um novo Viaduto do Chá projetado pelo arquiteto Eliziáro Bahiana, com uma solução art déco de grande beleza. Nas duas cabeceiras foram realizadas importantes obras: a casa do Conde de Prates, no Centro Histórico, veio abaixo,

2. PETRONE, op.cit., p.112 
substituída por um grande edifício encomendado pelo Conde Francisco Matarazzo ao arquiteto italiano Marcello Piacentini (TOGNON, 1999). $\mathrm{Na}$ outra cabeceira o edifício Mackenzie, sede da empresa Light \& Power, foi ampliado com grande cuidado pelo escritório Ramos de Azevedo e ao lado, em frente ao Teatro Municipal, o mesmo arquiteto do viaduto construiu a nova sede da loja de departamentos Mappin Stores, em 1939 (SEGAWA, 1998). Essa data é importante porque marca o momento em que o comércio dos artigos de luxo ${ }^{3}$ e os escritórios profissionais foram progressivamente instalando-se no Centro Novo. No Centro Histórico permaneceram ainda por muitos anos os escritórios de advocacia, pois a Faculdade de Direito e os Tribunais não se moveram, as sedes dos principais bancos, as corretoras, a Bolsa de Valores. Dessa época também são os últimos grandes edifícios construídos nos limites do Centro Histórico. Nice Lecocq Muller descreve o esgotamento dos terrenos disponíveis da seguinte maneira:

Já se disse que São Paulo é uma cidade cheia de ladeiras, sendo exatamente na área central que se tornam elas mais numerosas em virtude de ter o Núcleo Antigo as características de uma acrópole, descem, muitas vezes abruptamente, para as baixadas do Tamanduateí e do Anhangabaú, guardando consigo algo dos tempos coloniais. Assim são as ladeiras do Porto Geral e da Tabatinguera, voltadas para o Tamanduateí, e as do Ouvidor, de São Francisco ou do Riachuelo, que vão ter ao Anhangabaú. ${ }^{4}$

Nesta última ladeira, que em 1942 foi iniciada a construção do Edifício Riachuelo, em um terreno em forma de triângulo e grandes desníveis. $\mathrm{O}$ edifício com 17 pavimentos tem uma planta que se assemelha a uma letra "A", com o vértice arredondado abrindo-se para uma magnífica paisagem: os vales do rio ltororó (hoje Avenida 23 de Maio), Praça da Bandeira e Anhangabaú.

3. "Acompanhando o Mappin rumo ao "centro novo", um comércio sofisticado ali se instala: Casa Los Angeles, Joalheria Bento Loeb, Confeitaria Vienense, Cines Metro, Republica, Odeon e Royal, superam progressivamente os antigos estabelecimentos do "centro velho" em declínio... A principal concorrente do Mappin no "centro velho", não acompanhou seus passos: a Casa Alemã, que durante a Segunda Guerra foi obrigada a mudar de nome para Galeria Paulista de Modas, permaneceu na rua Direita, mas em 1959 encerrou suas atividades". SAES, op. cit., p.254.

4. MULLER, op. cit., p.155. 
FIGURA 8

Perspectiva original por Lindenberg \& Assumpção Engenharia em 1940 Arquivo COHAB-SP

FIGURA 9

Vale do Anhangabaú em 1940, com o Ed. Riachuelo circulado em vermelho.

TOLEDO, Benedito Lima de. "Prestes Maia e as origens do urbanismo moderno em São Paulo", Empresa das Artes,

Projetos e Edições Artísticas, S. Paulo 1996
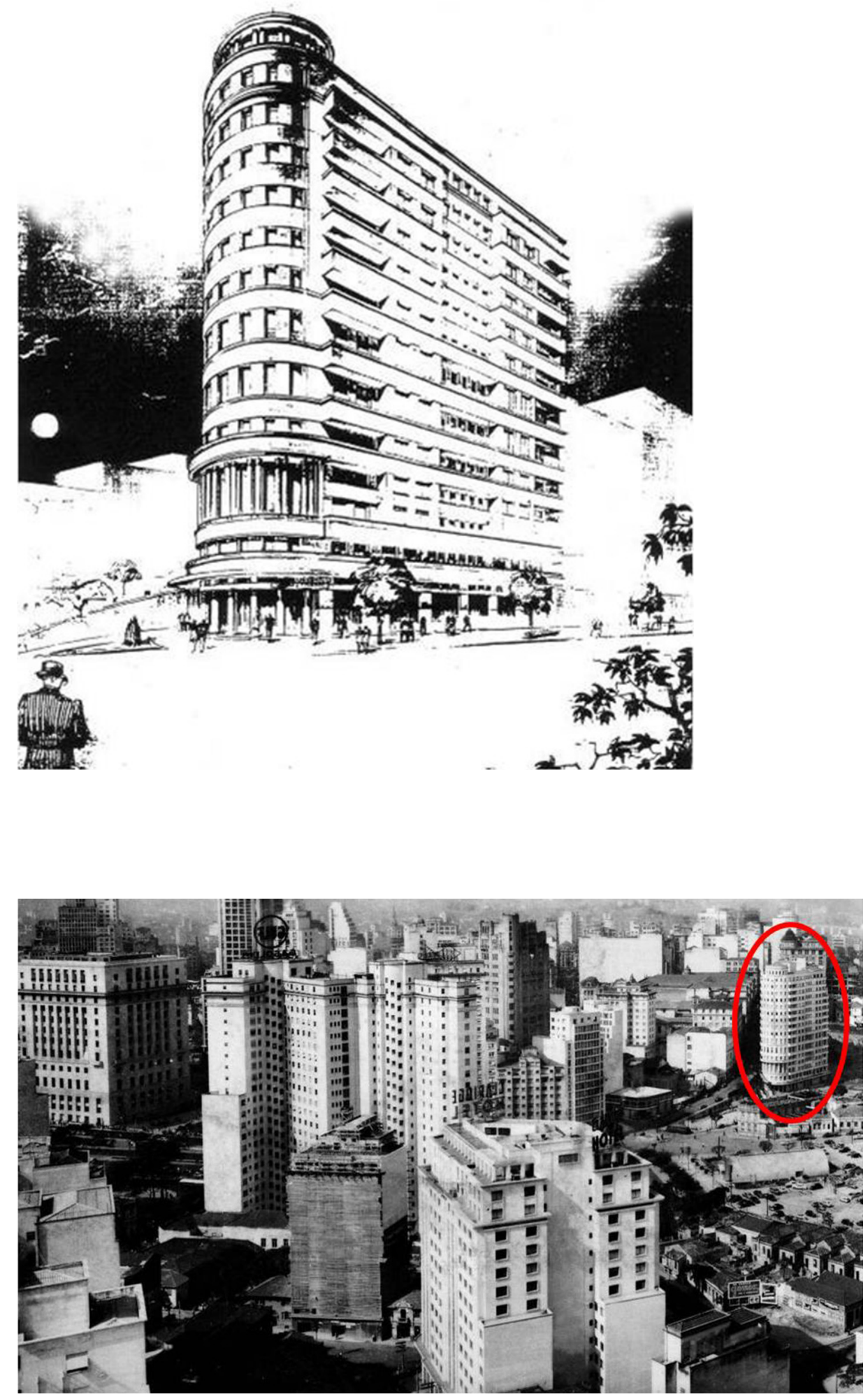

Rev. CPC, São Paulo, n.22 especial, p.193-216, abr. 2017. 
FIGURA 10

Avenida 9 de Julho na década de 1940 TOLEDO, Benedito

Lima de. "Prestes Maia e as origens do urbanismo moderno em São Paulo", Empresa das Artes,

Projetos e Edições Artísticas, S. Paulo 1996. Fotografia $p$.

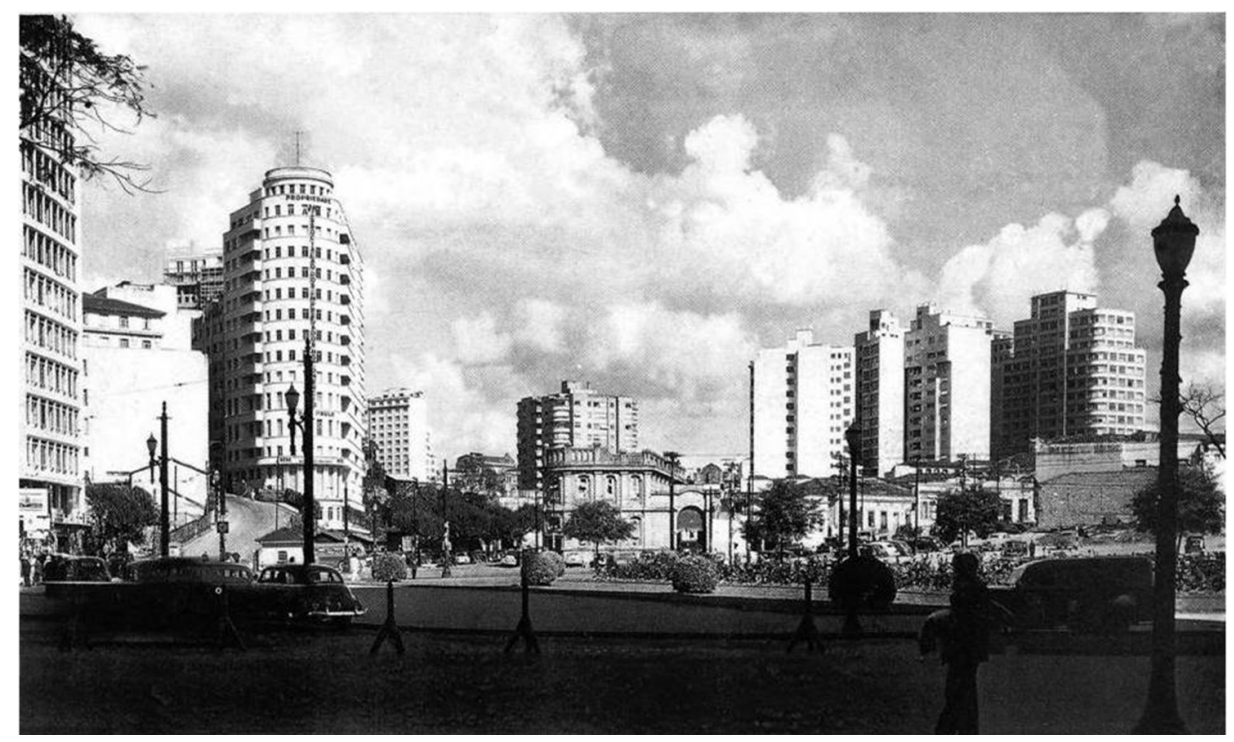

FIGURA 11

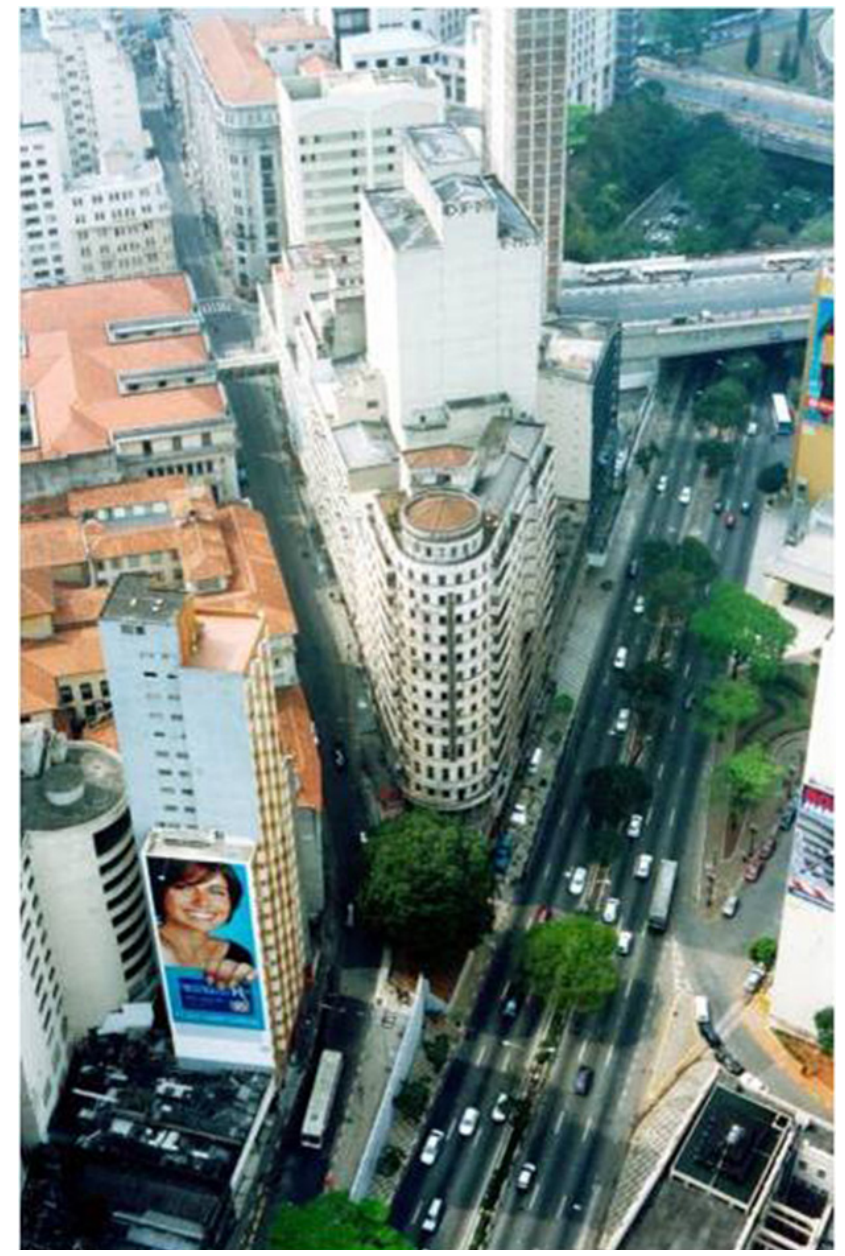


O projeto e a obra foram realizados entre 1942 e 1945 pelos Engenheiros Lindenberg e Assumpção ${ }^{5}$. Nesses anos, durante a Segunda Guerra Mundial, havia uma enorme carência de materiais de construção, sobretudo ferro em barra, ainda importado. O projeto buscava, através de pequenos vãos e muitos pilares, diminuir as dificuldades estruturais. Apesar dos muitos anos de abandono, o edifício está em excelente estado de conservação estrutural, pois nenhum reforço foi necessário na atual transformação. $\mathrm{O}$ esqueleto em concreto armado recebeu alvenarias em tijolos comuns assentados com argamassa de cal e areia, que se procurou respeitar. A estrutura das coberturas era construída por tesouras de peroba cobertas com telhas cerâmicas.

O revestimento externo original das fachadas era de "massa raspada", argamassa de cimento, cal extinta e pó de mármore (1:4:12) devidamente "impermeabilizado" por emboço formado por uma parte de cimento por 10 partes de argamassa de cal e areia (1:4). A volumetria de grande interesse apresenta traços típicos da arquitetura "modernista" ou protomoderna típica da década de 1940, alternando balcões e janelas corridas. Pelo interesse arquitetônico da fachada, ela foi listada como de interesse histórico pelo Conselho Municipal de Preservação do Patrimônio Histórico de São Paulo (Conpresp) e pelo Conselho de Defesa do Patrimônio Histórico, Arqueológico, Artístico e Turístico do Estado de São Paulo (Condephaat). A planta também é típica daquela época: havia um corredor interno ao longo do qual distribuíam-se salões com $45 / 50 \mathrm{~m}^{2}$ de área útil. No fundo do corredor havia sanitários coletivos. No Edifício Riachuelo, entre os dois blocos do "A" havia uma escada, um vestíbulo com três elevadores e um poço de ventilação.

O primeiro proprietário foi a Associação dos Empregados do Comércio de São Paulo (1944-78). Nesse período o edifício recebeu o nome de Palácio do Comerciário Alexandre Marcondes Filho e ocupava apenas a parte inferior do edifício com atividades sociais, restaurante e salas de aula. Os demais andares foram vendidos. O espaço ocupado pela Associação foi em

5. A Construtora Lindenberg \& Assumpcão Engenheiros Civis, com sede a Rua Boa Vista, 65, foi fundada em 1940. Assinava as plantas como responsável técnico o engenheiro Luiz Antonio Fleury de Assumpção. Em 1945 a construtora tinha 731 empregados. As informações constam do processo da PMSP - Secretaria de Obras e Serviços- Departamento de Arquitetura, n. 54.260/45 e no livro de SAES, op. cit., p. 256 
seguida utilizado por uma escola de contabilidade, que quando desocupou o edifício, pouco a pouco, ele foi ficando vazio. Em 1994 o prédio foi invadido por moradores de rua do Movimento Sem Teto. A expulsão dos invasores pela polícia acabou gerando profundas depredações, como a destruição das portas, janelas, áreas de sanitários, elevadores. As tubulações de águas pluviais, feitas de ferro fundido, foram arrancadas em muitos andares, de modo que quando chovia os andares ficavam inundados, arruinando o parquet de madeira, corredores e escadas.

FIGURA 12

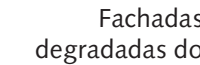
Edifício Riachuelo. Fotografia: Sonia Gouveia.

FIGURA 13

Fachadas do Edifício Riachuelo. Fotografia: Sonia Gouveia.
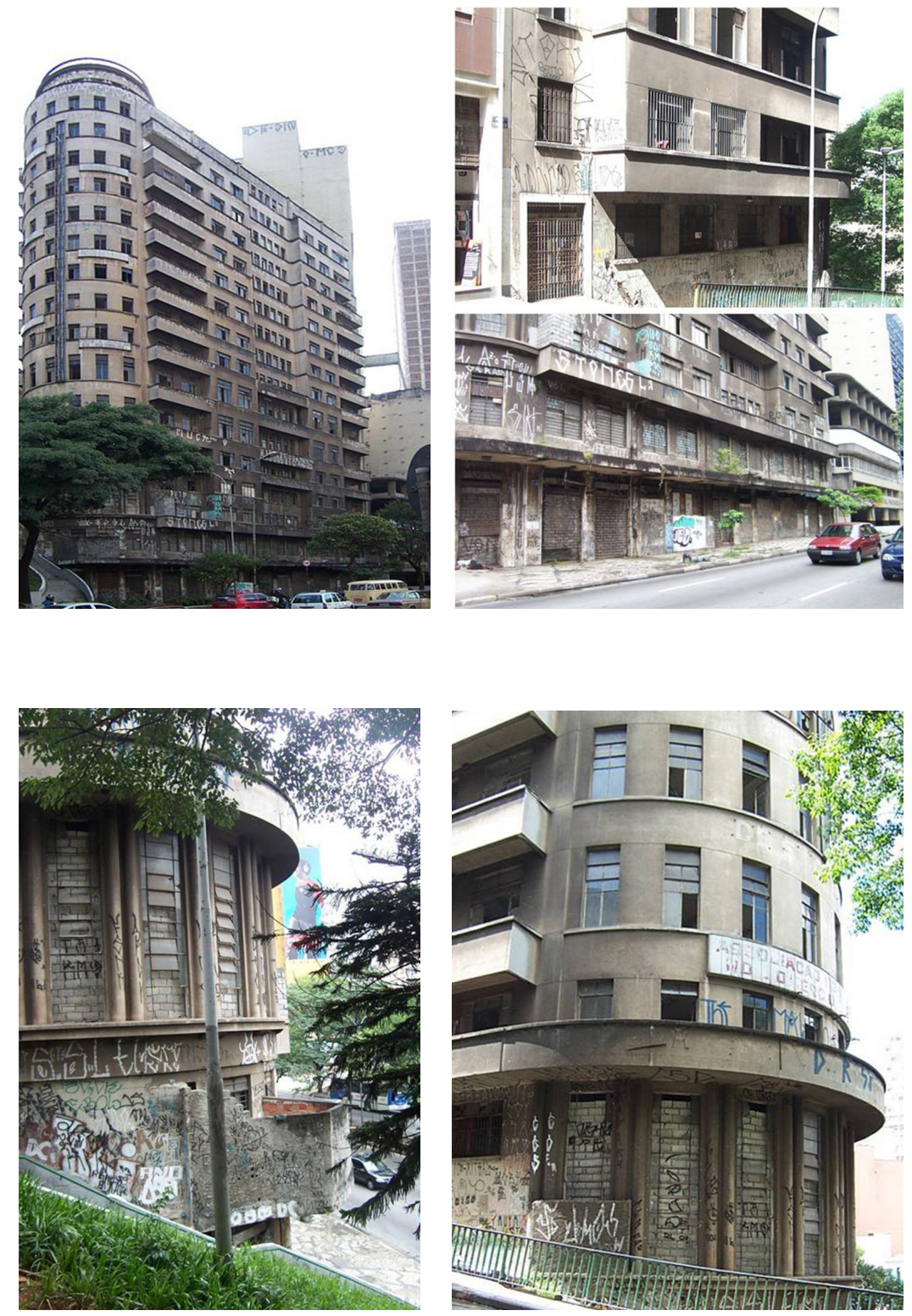
FIGURA 14

Fachadas do Edifício Riachuelo.

Fotografia: Sonia

Gouveia.

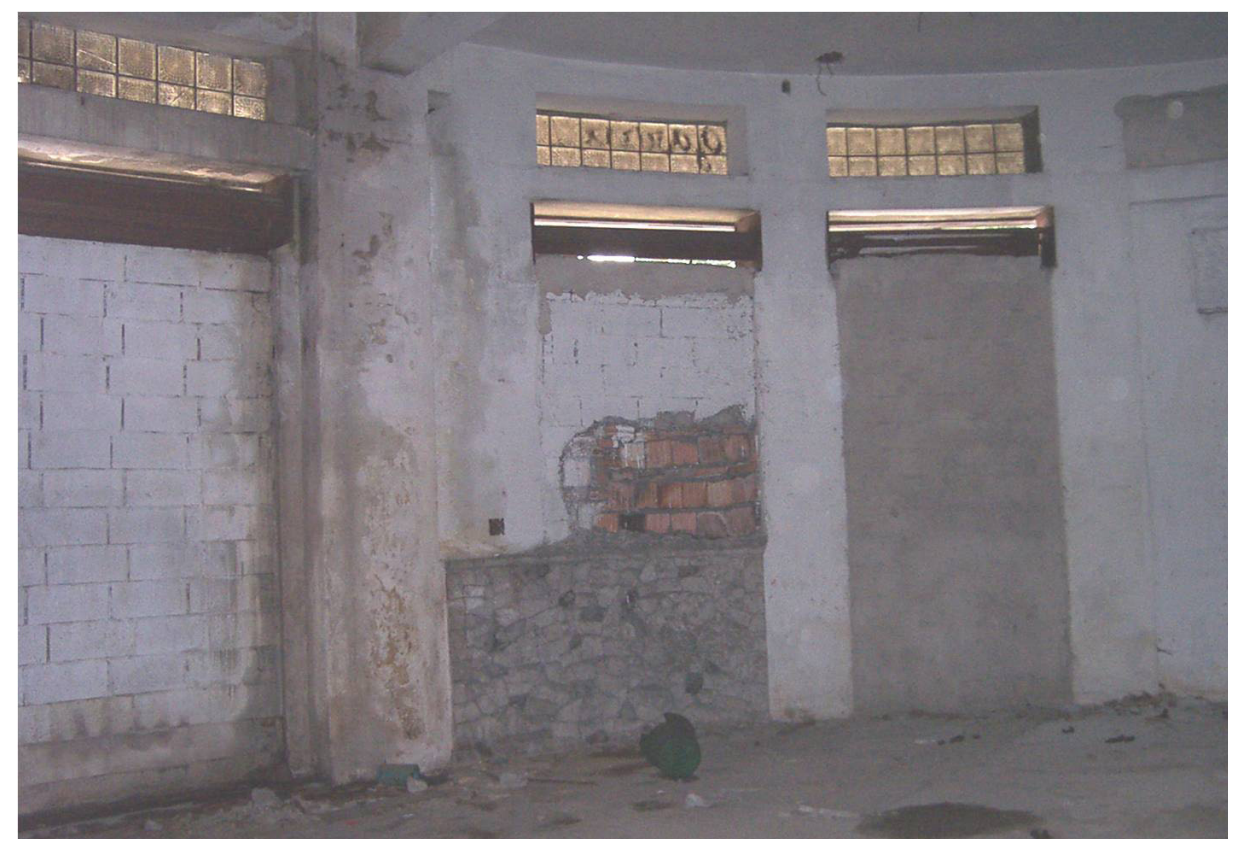

FIGURA 15

Fachadas do Edifício

Riachuelo.

Fotografia: Sonia

Gouveia.

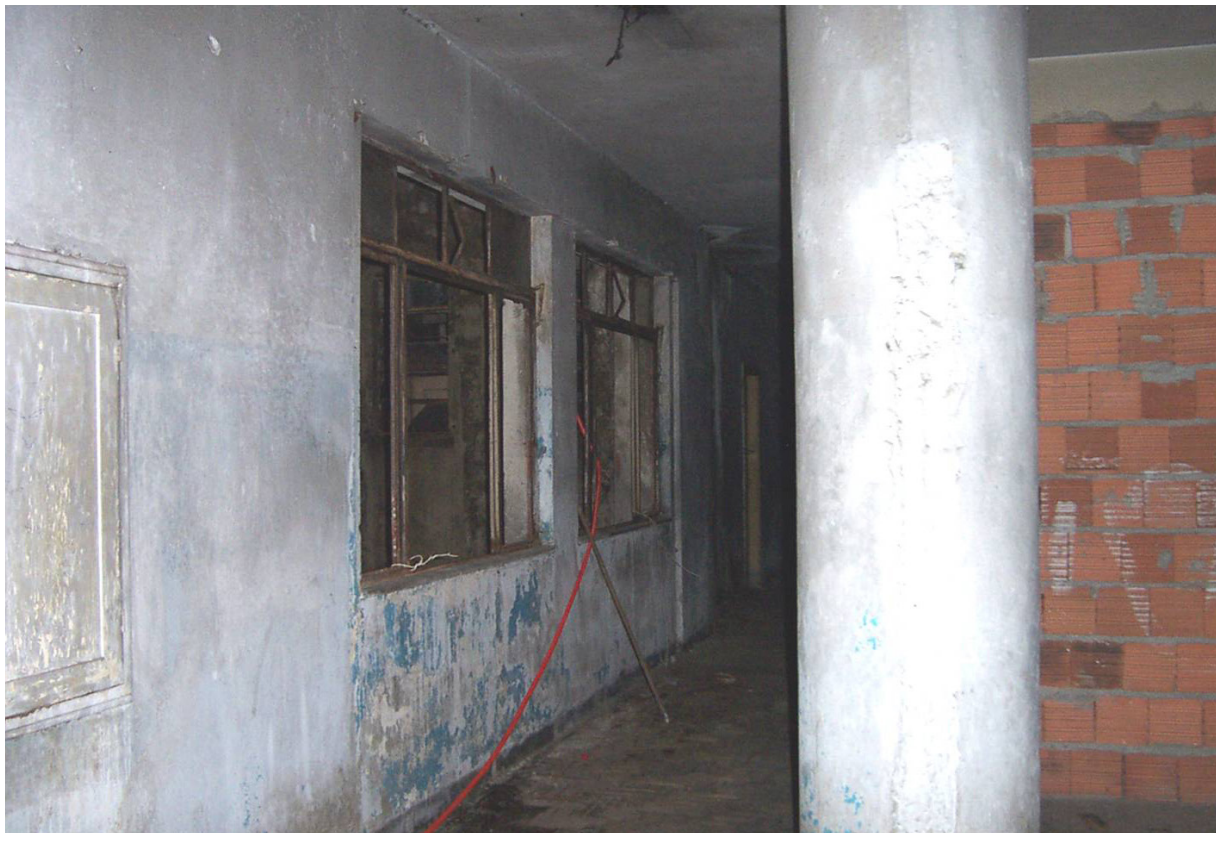

Rev. CPC, São Paulo, n.22 especial, p.193-216, abr. 2017 
FIGURA 16

Fachadas do Edifício Riachuelo.

Fotografia: Sonia

Gouveia.

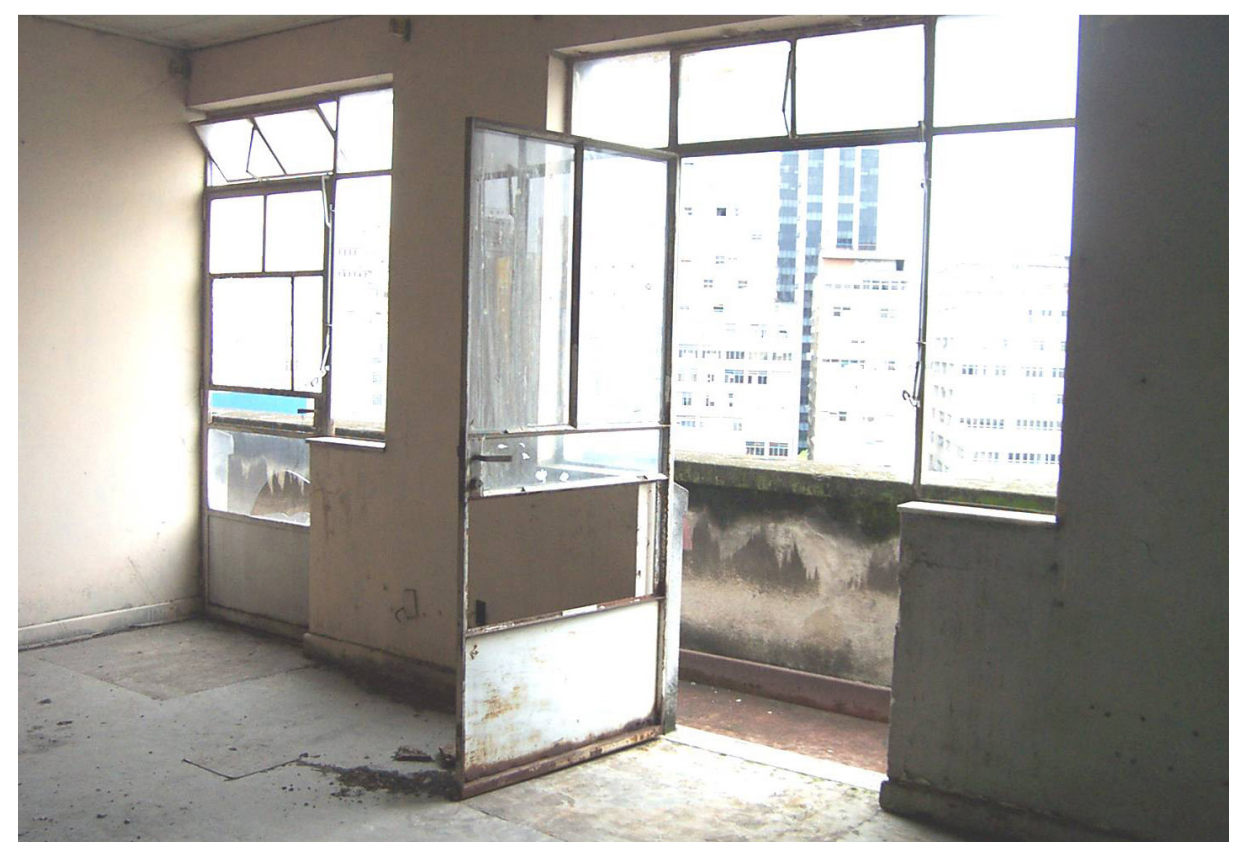

FIGURA 17

Fachadas do Edifício Riachuelo.

Fotografia: Sonia Gouveia.

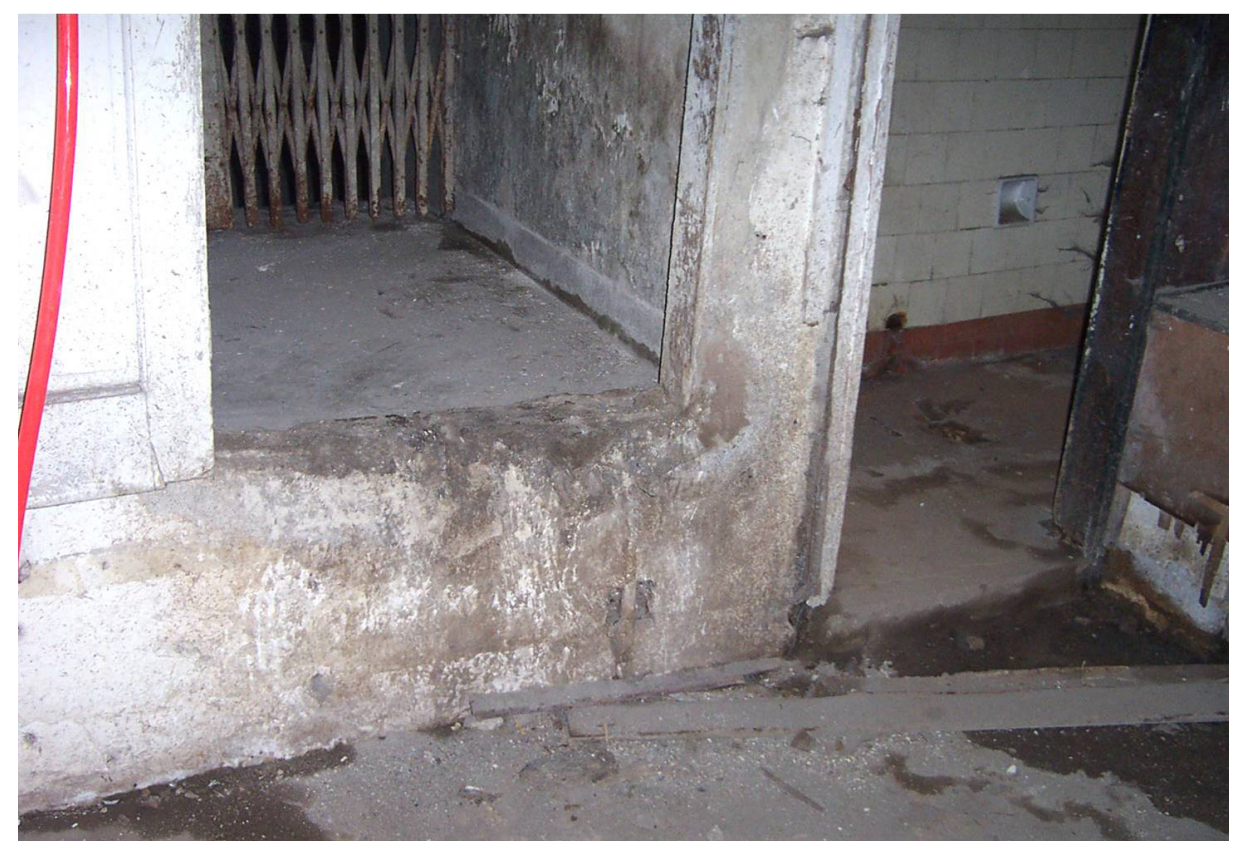

Rev. CPC, São Paulo, n.22 especial, p.193-216, abr. 2017 
FIGURA 18

Fachadas do Edifício Riachuelo. Fotografia: Sonia Gouveia.

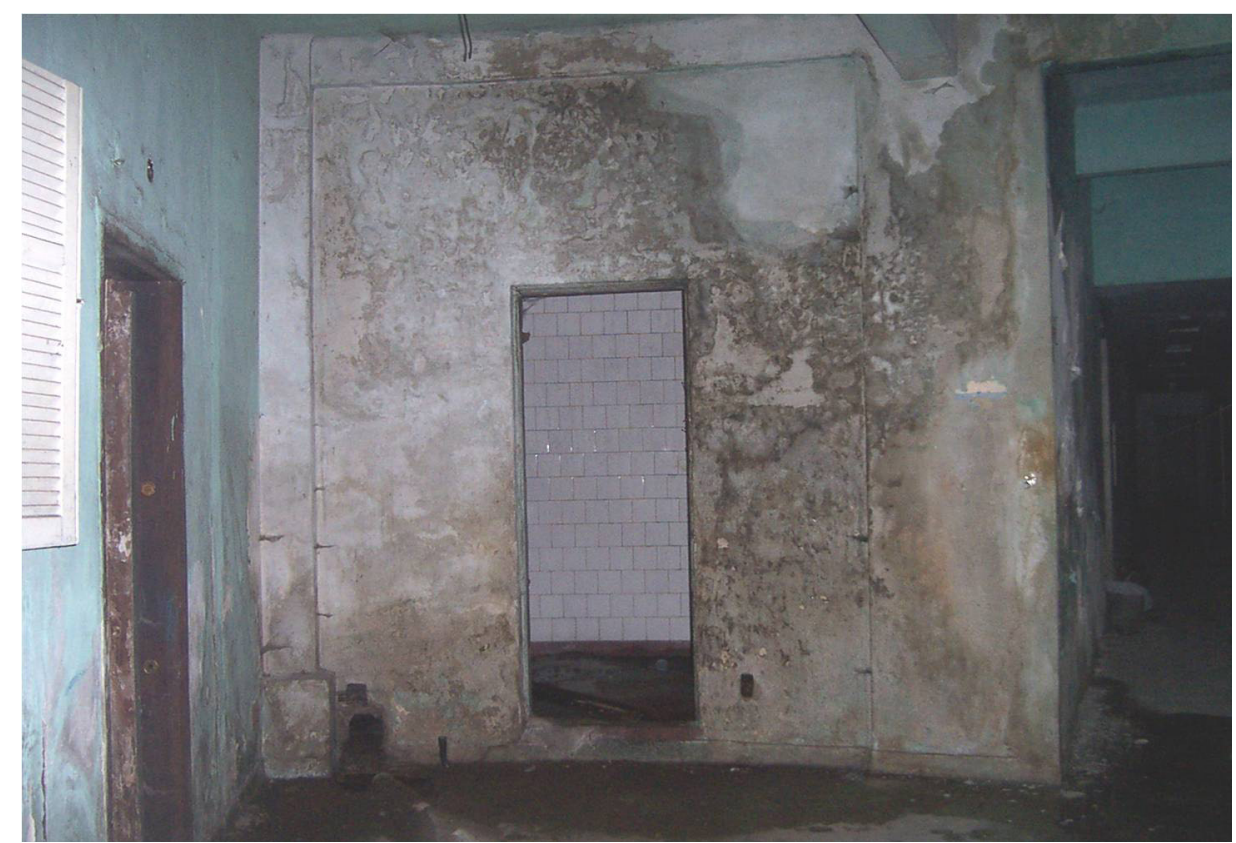

A prefeita Marta Suplicy (PT) durante sua gestão (2000-2004) iniciou um programa denominado Morar no Centro ${ }^{6}$, que visava a ocupação do Centro Histórico com a mudança da sede da prefeitura para o antigo edifício do Conde Matarazzo, na Praça do Patriarca, e da mudança da maioria das secretarias municipais para edifícios vazios do Centro Histórico. Esse Programa foi acompanhado pela transferência para o Centro Histórico de muitas secretarias estaduais entre as quais, por exemplo, o Metrô e a Companhia Paulista de Trens Metropolitanos(CPTM). O programa foi realizado como estímulo para que o Centro Histórico fosse ocupado também por habitações de interesse social. A ideia era viabilizar um número maior de moradias para as camadas de baixa renda que trabalham no centro. $\mathrm{O}$ programa apresentava três diretrizes principais: dar prioridade à compra $\mathrm{e}$ reforma de edifícios vazios; construir novas unidades onde fosse possível, como em terrenos residuais resultantes das desapropriações necessárias

6. Prefeitura do Município de São Paulo, Secretaria da Habitação e Desenvolvimento Urbano. Caderno Programa Morar no Centro, SEHAB, 2004. 
para a construção da linha Leste-Oeste do Metrô, e finalmente proporcionar diversidade social nos bairros centrais. A Companhia Metropolitana de Habitação de São Paulo (Cohab-SP), responsável pela compra e execução das obras, decidiu implantar em alguns projetos, e neste, em particular, um sistema de "locação social" visando atender atender os moradores de baixa renda, que têm dificuldade para se enquadrar dentro das normas de financiamento, em geral porque não conseguem comprovar uma renda regular.

FIGURA 19

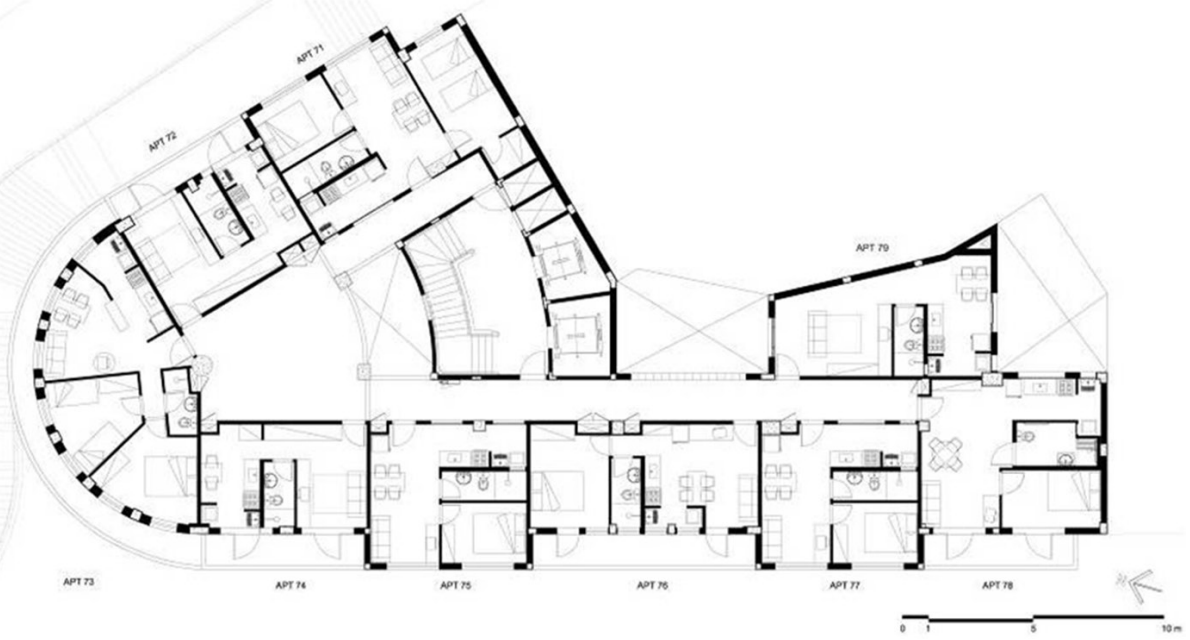

FIGURA 20

Planta do apartamento. Desenho: Paulo

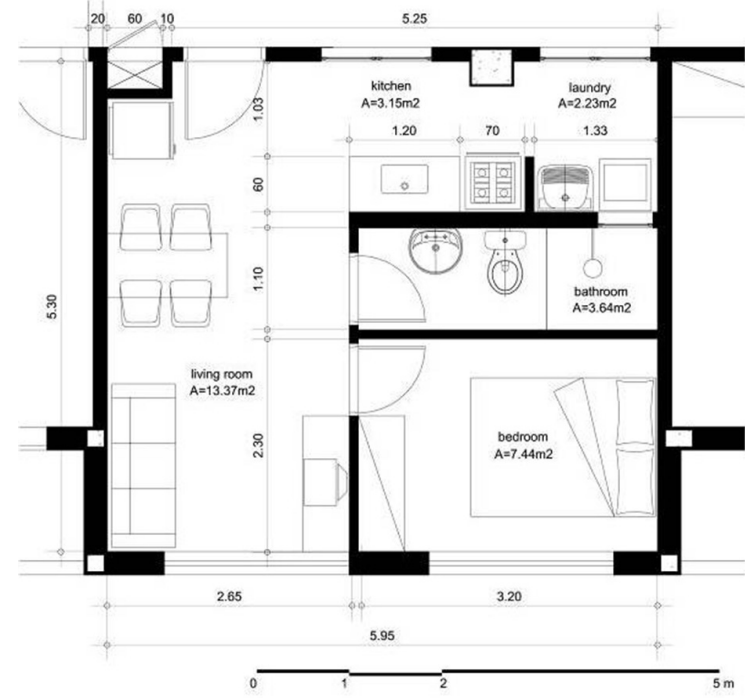


FIGURA 21

Comparação da fachada do Edifício Riachuelo Antes e após a reabilitação. Fotografias: Sonia Gouveira.

FIGURA 22

Comparação da fachada do Edifício Riachuelo Antes e após a reabilitação. Fotografias: Sonia Gouveira.
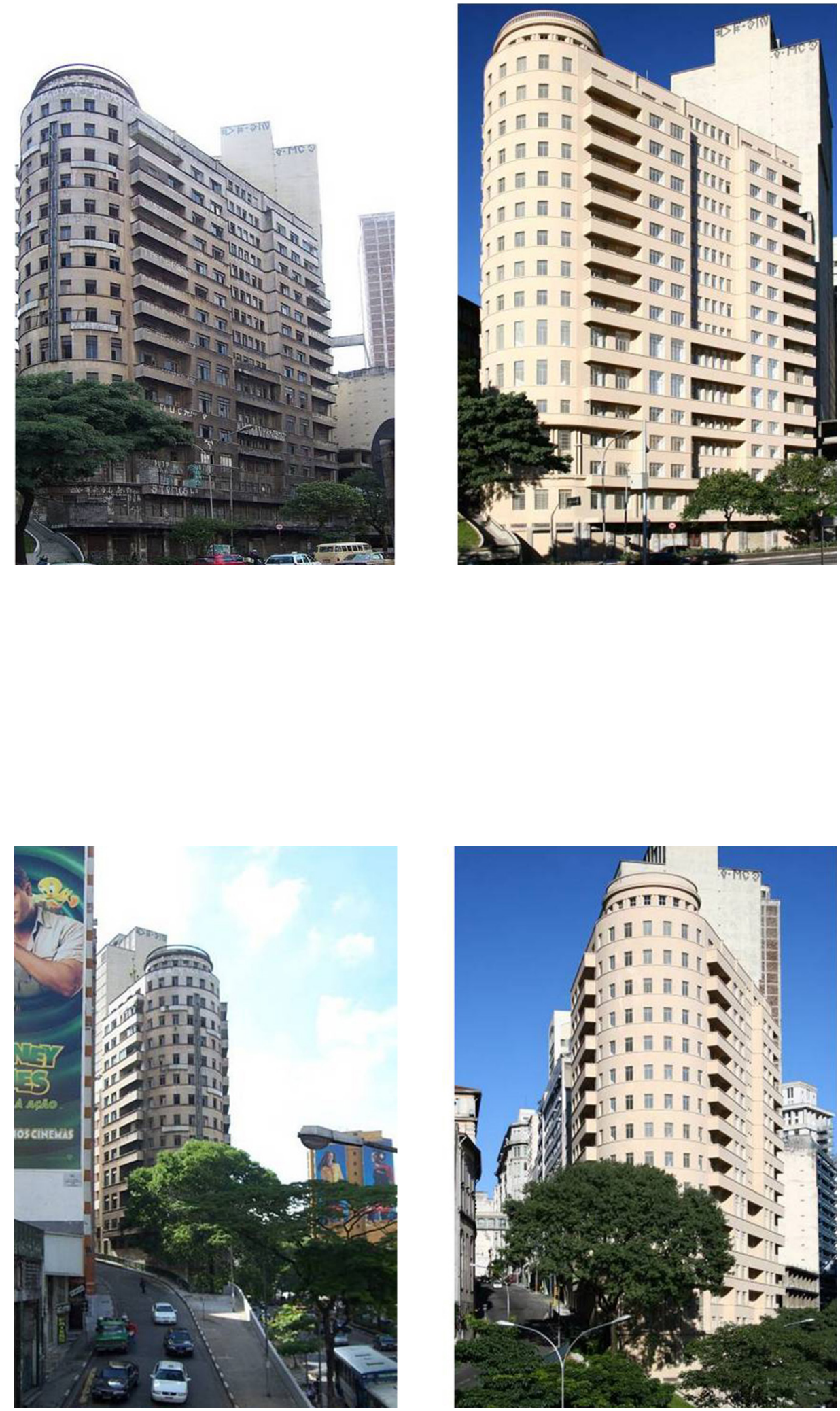


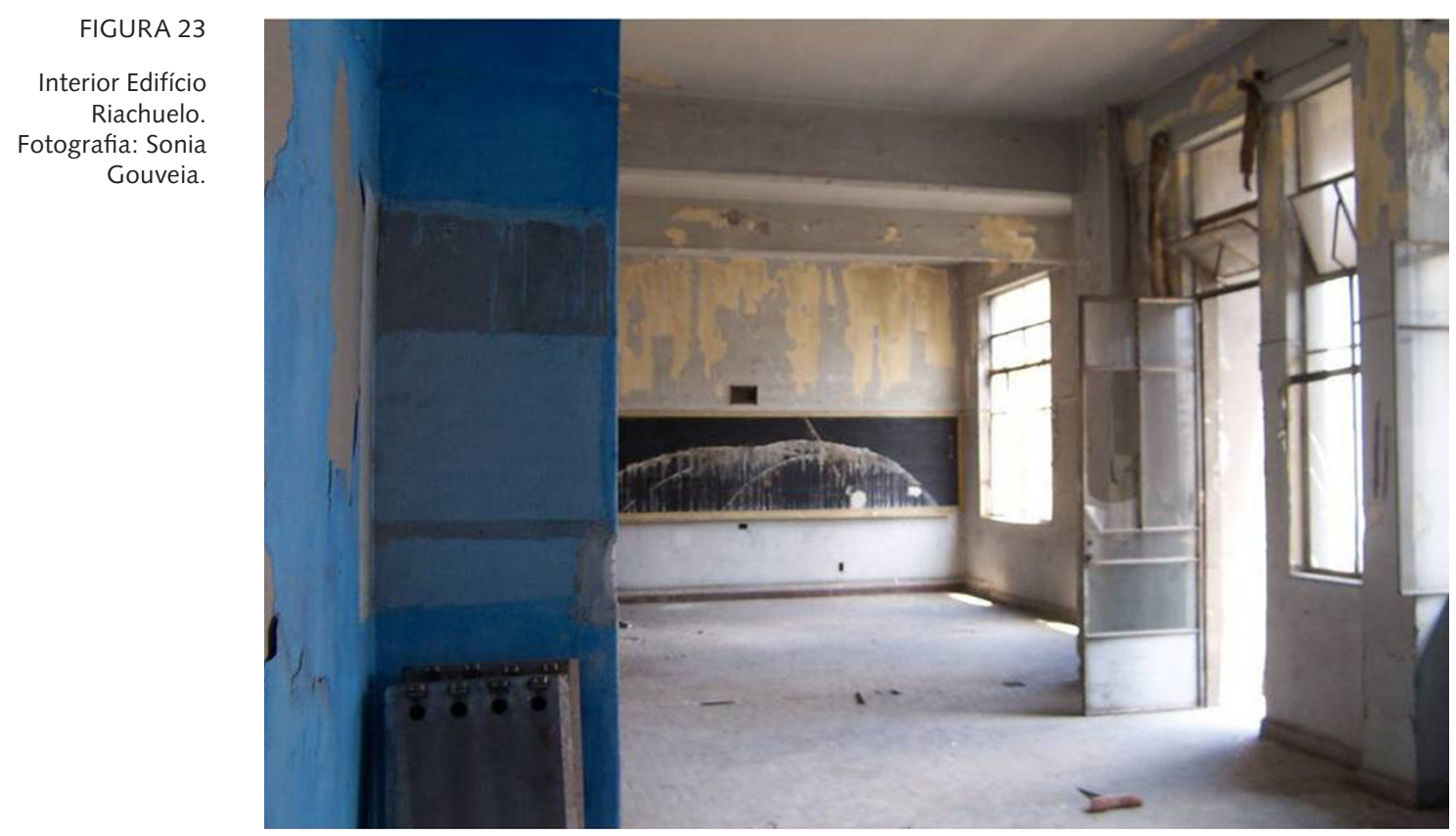

FIGURA 24

Interior Edifício Riachuelo após as obras. Fotografia: Sonia Gouveia.

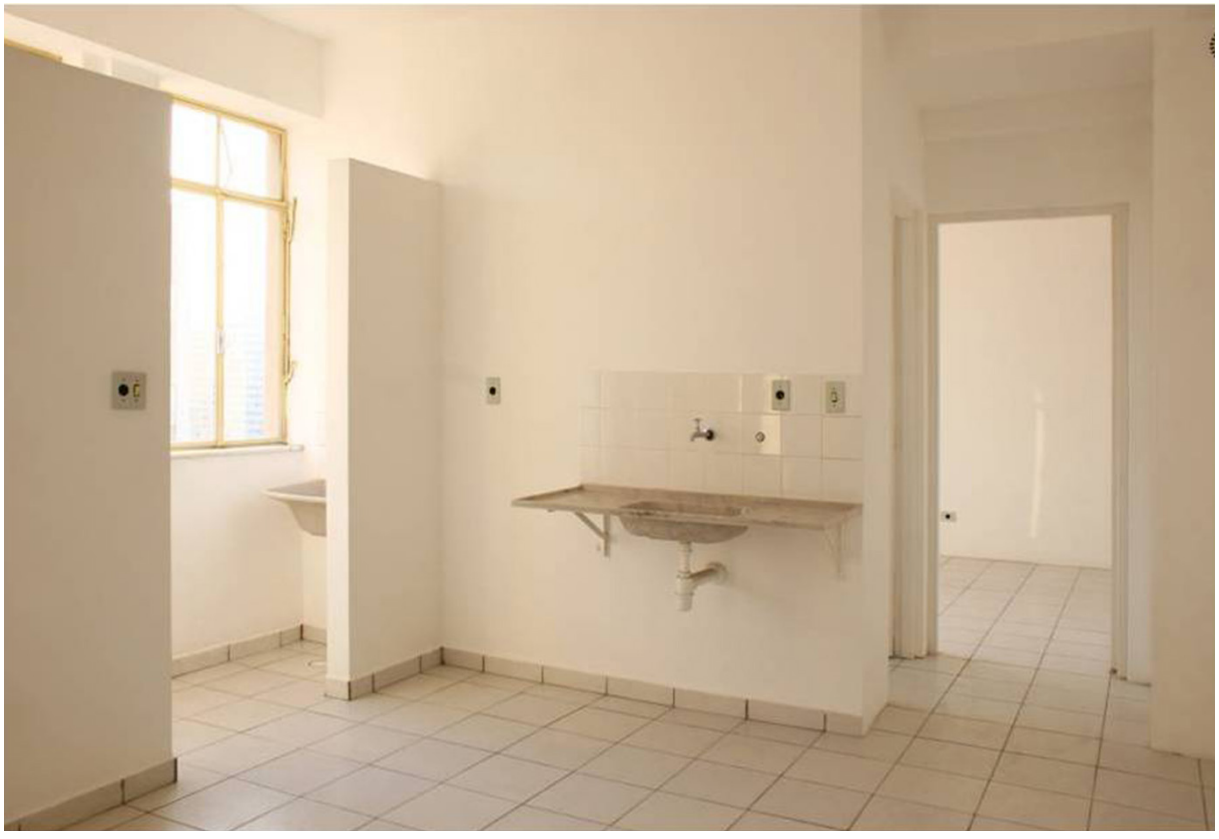




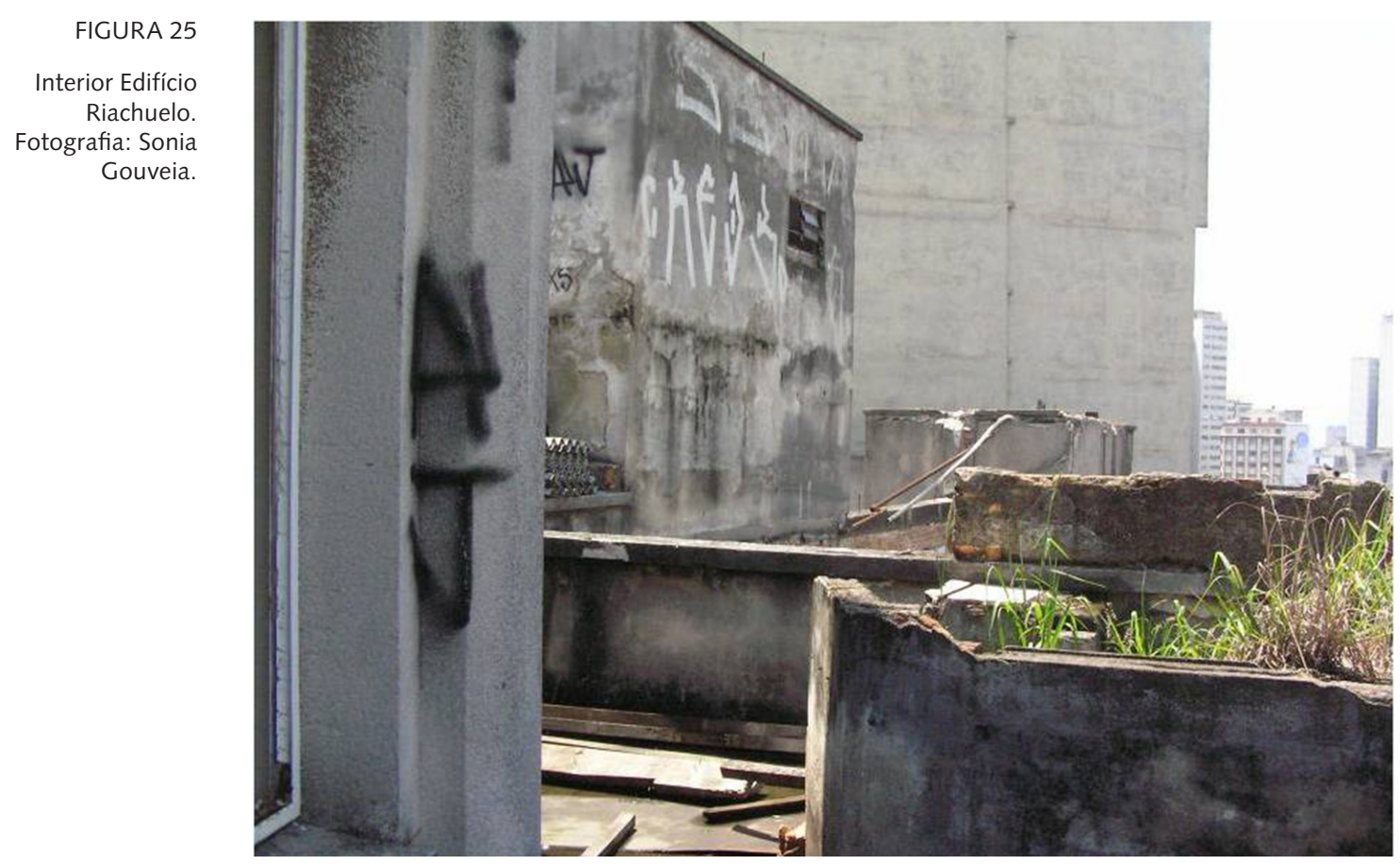

FIGURA 26

Interior Edifício Riachuelo após as obras. Fotografia: Sonia Gouveia.

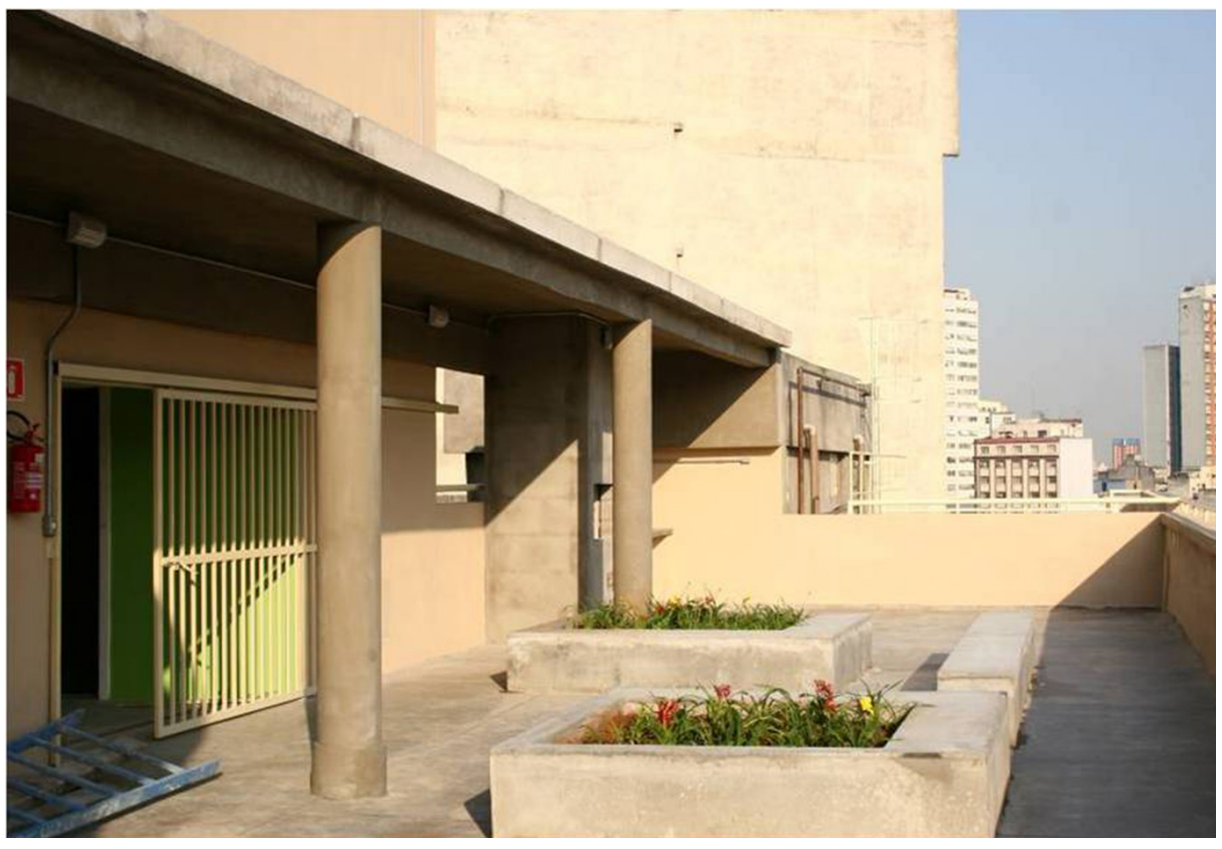


FIGURA 27

Terraço do Edifício Riachuelo degradado antes da reabilitação.

Fotografia: Sonia Gouveia.
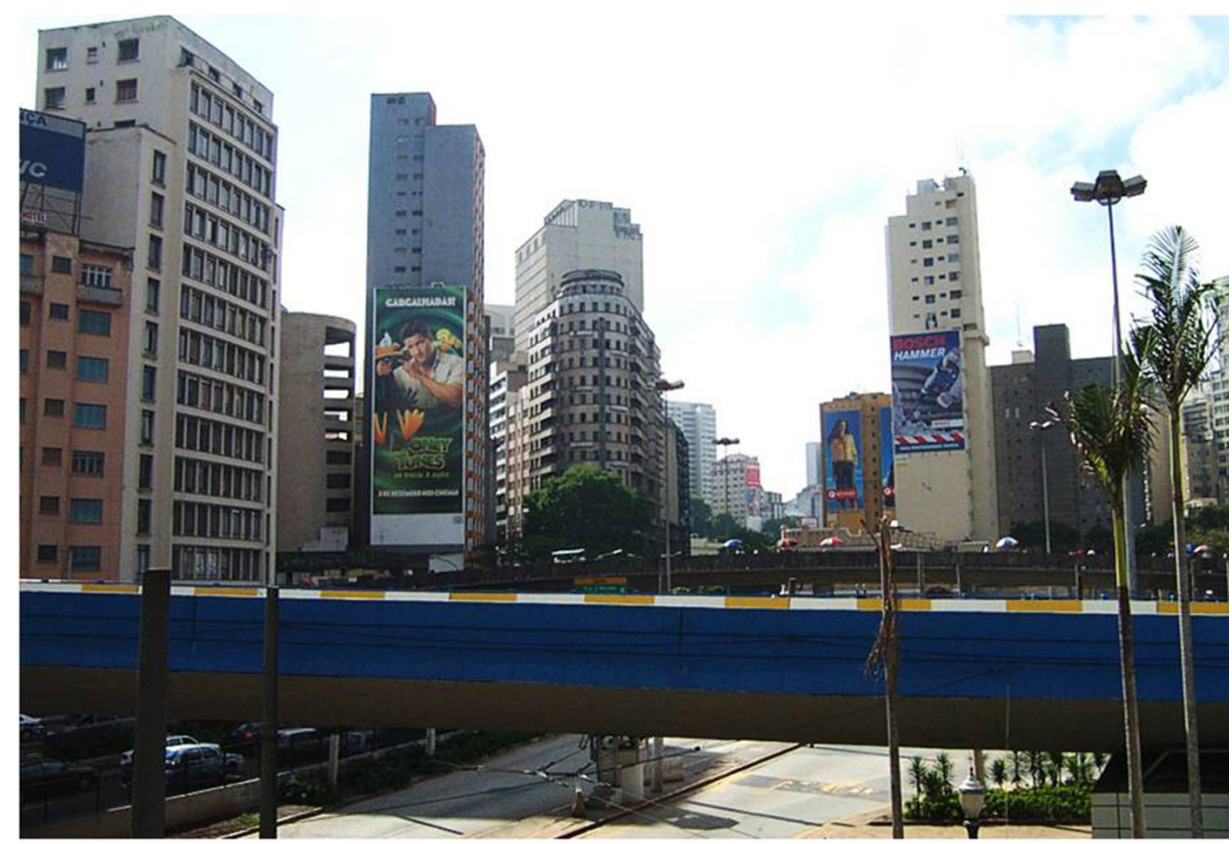

FIGURA 28

Terraço do Edifício

Riachuelo após as

obras. Fotografia:

Sonia Gouveia.

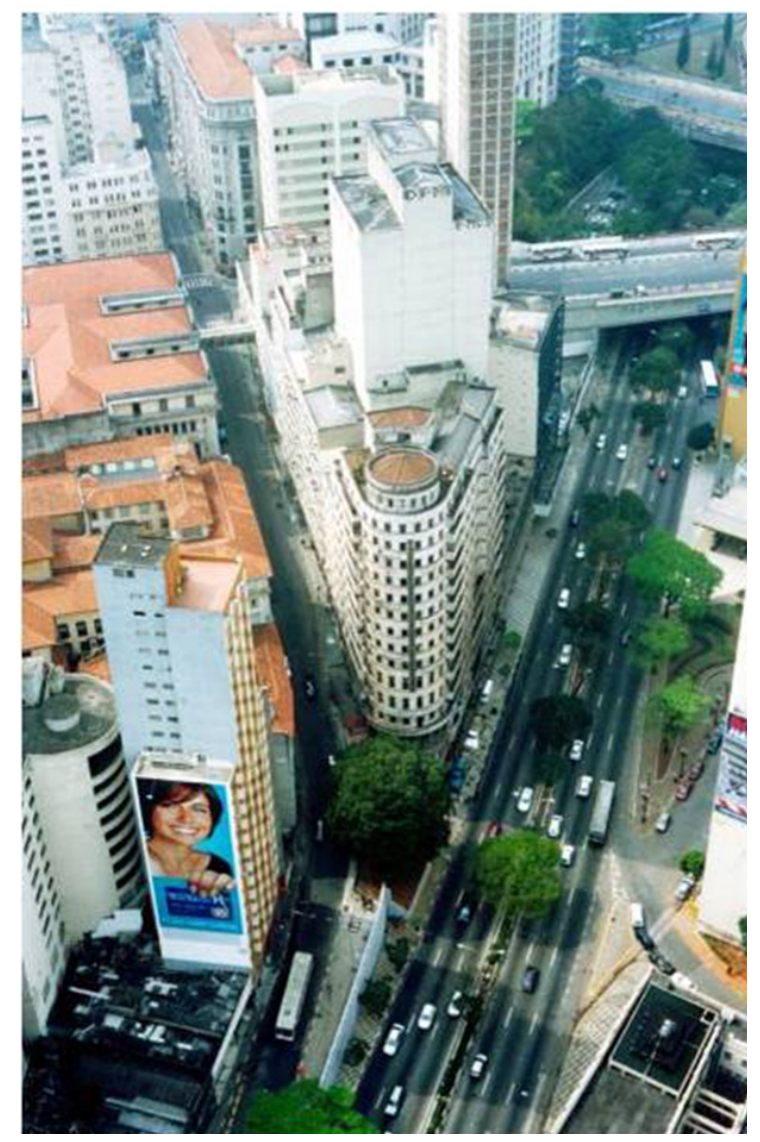


Paulo Bruna Arquitetos Associados foi contratado pela Cohab-SP para reabilitar o edifício alterando seu uso para apartamentos. A área do terreno é de $516 \mathrm{~m}^{2}$ e a área construída ${ }^{7}$ total $7.870,54 \mathrm{~m}^{2}$. A recuperação procurou respeitar a lógica da composição original. Entre os salões de escritórios havia sólidas paredes de alvenaria de tijolos comuns que foram mantidas. Assim, basicamente cada escritório transformou-se num apartamento. Foi possível acomodar 120 unidades com áreas variando de $27,4 \mathrm{Om}^{2}$ a $47,22 \mathrm{~m}^{2}$ de área útil. Muitos têm balcões com portas e janelas externas privativas. Em cada unidade foi construído um banheiro, cozinha e área de serviço com tanque e máquina de lavar. As divisões internas já concluídas foram executadas em alvenaria leve para não sobrecarregar a estrutura de concreto armado. $\mathrm{O}$ anteprojeto da reforma previa uma escada de segurança no vazio central do poço de ventilação, mantendo a escada existente aberta para o hall dos elevadores. No projeto final foi possível garantir as normas de segurança exigidas pelo Corpo de Bombeiros, eliminando a escada enclausurada e apenas isolando.

O edifício foi concluído em 2008 e imediatamente ocupado por moradores, boa parte deles transferidos do Edifício San Vito, que ia ser demolido. Os atuais moradores organizaram-se e administram o condomínio com energia e competência.

\section{REFERÊNCIAS}

HALL, Michael. lmigrantes na cidade de São Paulo. In: Paula Porta (org.) História da cidade de São Paulo. São Paulo: Paz e Terra, 2004. v.3. cap. 4, p.121.

MEYER, Regina M. P. Metrópole e urbanismo: São Paulo anos 1950. Tese (Doutorado em Arquitetura e Urbanismo) - Faculdade de Arquitetura e Urbanismo, Universidade de São Paulo, São Paulo, 1991.

MOMBEIG, Pierre. Aspectos geográficos do crescimento de São Paulo. O Estado de S. Paulo, especial, 25 jan. 1954. (transcrito no Boletim Paulista de Geografia, n. 16, p. 72, mar. 1954.).

MULLER, Nice Lecocq. A área central da cidade. In: ASSOCIAÇÃO DOS GEÓGRAFOS BRASILEIROS (org.). A cidade de São Paulo, estudos de geografia urbana: aspectos da metrópole paulista. São Paulo: Companhia Editorial Nacional, 1958. v. 3. cap. III, p. 132.

7. O coeficiente de aproveitamento da obra e de 14,88 . Essa obra não seria viável com os atuais índices urbanísticos. Talvez seja essa uma das razões do abandono de muitos edifícios no centro histórico; se demolido, o edifício não poderia ser reconstruído com a mesma área. A área comum total é de $2.741,22 \mathrm{~m}^{2}$, que, dividido por 120 unidades, dá, em média, $22,84 \mathrm{~m}^{2}$ por apartamento. 
SAES, Flavio. São Paulo republicana: vida econômica. In: História da cidade de São Paulo. São Paulo: Paz e Terra, 2004. v.3 p.240.

SEGAWA, Hugo. Arquiteturas no Brasil, 1900-199o. São Paulo: Edusp, 1998. p. 58-59.

TASCHNER, Suzana Pasternak. Política habitacional no Brasil: retrospectiva e perspectivas, Cadernos de Pesquisa do LAP, set.-out. 1997.

TOGNON, Marcos. Arquitetura italiana no Brasil: a obra de Marcello Piacentini. Campinas: Editora da Unicamp, 1999. 